\title{
Gender and Politics
}

\author{
Jeffrey C. Isaac
}

$T$ he gendering of politics, and the politics of gender, are fundamental themes of human life. Back in March 2010 we featured these themes in our journal's first-ever special theme issue. At over 400 pages, the issue was the longest single issue in the history of Perspectives and, I would be willing to bet, the history of APSA journal publishing more generally. It also launched our journal's then-new cover design, which featured a photo of an impoverished Nigerian woman holding a machete with which to chop pieces of dying mangrove wood for sale. In preparing for the Introduction you are now reading, I went back and re-read that old issue of our journal. It is amazing how well it holds up, and how much it anticipates the themes discussed in this issue, also centered on the theme of Gender and Politics.

We have chosen to revisit the gender theme for a variety of reasons worth noting.

One is that gender issues were raised in a very public way at last year's APSA meeting in Chicago (see Beth McMurtrie's report on the meeting, "Political Science is Rife With Gender Bias, Scholars Find," published in the August 30 Chronicle Review). Much of the discussion centered on the findings presented in Daniel Maliniak, Ryan Powers, and Barbara F. Walter's piece in the October 2013 International Organization, "The Gender Citation Gap in International Relations." But for many these findings were the launching point for discussing a much larger set of issues related to the gendering of political science. One interesting forum of discussion is the special symposium on "the gender gap" organized by The Monkey Cage (9/30/2013), which led with a piece by 2012-13 APSA President Jane Mansbridge, whose Address is featured in this issue. These issues have indeed been the focus of a number of APSA committees, most notably the Ad Hoc Committee on Workable Solutions to Advancing Women in the Profession chaired by Kristen Renwick Monroe. They are of pressing concern to many APSA members, and so they were a topic of conversation at our journal's September 2013 board meeting. Our board decided to make the gender citation question a major topic at our Spring 2014 meeting in Chicago. And we also decided to plan an issue of the journal centering on the theme of gender.

The second reason we have centered this issue on the theme of gender is more theoretical: the fundamental importance of gender as an ever-present structuring category of social being and thus of social science. I offered some thoughts on the importance of gender to political science in the Introduction to the March 2010 special issue. But here I can do no better than to quote from Karen Beckwith and Lisa Baldez in their editorial statement in the inaugural issue of our sister publication Politics \& Gender, which first appeared in March 2005: "We launch Politics \& Gender with the conviction that the study of women and politics, and the gendered analysis of politics, benefit and strengthen political science. We hold the reverse conviction as well: the tools of political analysis advance and strengthen our understandings of women and of gender. . our primary purpose is to publish research on women and politics and on politics and its gendered analysis. Gender cuts through every aspect of politics. In Politics \& Gender, we seek to represent the full array of questions, issues, and approaches within the discipline. We envision each issue as a showcase of work across all the major subfields of political science, including (but not limited to) political theory, comparative politics, international relations, and U.S. politics."

The range of work on gender published in this issue of Perspectives affirms the truth of Beckwith and Baldez's words. The fact that the work in this issue of Perspectives was largely unsolicited, and simply came to us in the normal course of our editorial business, is a further sign of how central gender themes are to our discipline (something also documented in the just-published Oxford Handbook of Gender and Politics, edited by Georgina Waylen, Karen Celis, Johanna Kantola, and S. Laurel Weldon). Indeed, there are striking and entirely fortuitous overlaps between this issue of Perspectives and Politics \& Gender. This issue contains contributions from four members of the editorial board of Politics \& Gender-Kimberly Cowell-Meyers, Cynthia Enloe, Heath Fogg Davis and Jane Mansbridge - and one officer of the Women and Politics section that sponsors the journal-Celeste Montoya. Two other officers of this section-Mala Htun, its President, and Dara Strolovitch-also serve on our board, as does Timothy Kaufman-Osborn who serves on the editorial board of Politics \& Gender. These overlaps demonstrate inextricable links between gender scholarship and political science as a discipline. 
But more important than the centrality of gender to political science is its centrality to politics. Within days of sitting down to write this Introduction the following four news items came across my desk:

* The November 6, 2013 release of a UN report, Women and Natural Resources: Unlocking the Peacebuilding Potential, which contends that: "As primary managers and users of natural resources in many conflict-affected contexts, women have a key role to play in building peace. However, they remain largely excluded from owning land, benefiting from resource wealth or participating in decision-making about resource management. Excluding women is clearly a missed opportunity. Indeed, peace and development will only be achieved when both men and women in conflict-affected and fragile societies access and benefit from natural resources in an equitable and sustainable way."

* A November 4, 2013 Newsweek photojournalistic feature, "Grab and Run: Kyrgyzstan's Bride Kidnappings," reporting that "In Kyrgyzstan, as many as $40 \%$ of ethnic Kyrgyz women are married after being kidnapped by the men who become their husbands, according to a local NGO. Two-thirds of these bride kidnappings are nonconsensual-in some cases, a 'kidnapping' is part of a planned elopement-and while the practice has been illegal since 1994, authorities largely look the other way."

* A November 25, 2013 Voice of America story, "UN Expresses Concern on International Day to End Violence Against Women," which reports that according to the Joint United Nations Program on HIV/AIDS, every hour 50 young women become newly infected with HIV, many as a result of sexual violence. The piece quotes Dr. Mariangela Simao, UNAIDS Director of Rights, Gender, Prevention and Mobilization: "Lots of the gender-based violence [is] sexually related. There is a lot of data right now showing that most of the violence against women happens in the context of intimate partner violence - domestic violence. And many times it takes the face of non-consensual sex, which is a polite way to say rape."

* A November 20, 2013 White House press release marking the annual Transgender Day of Remembrance: "Today, November $20^{\text {th }}$, communities across the country and around the world will mark Transgender Day of Remembrance. This day is an opportunity to remember those who have lost their lives to violence and injustice because of their gender identity or gender expression. . . The Obama Administration remains committed to preventing violence against all people, including all members of the LGBT community. Four years ago, President Obama signed the Matthew Shepard and James Byrd Jr. Hate Crime Prevention Act, which greatly expanded the federal government's ability to prosecute hate crimes. The law marked the first time that the words, 'sexual orientation' and 'gender identity' appeared in the U.S. Code, and enables the Justice Department to prosecute in certain circumstances hate crimes committed because of a person's actual or perceived race, color, religion, national origin, gender, sexual orientation, gender identity, or disability."

Such reports underscore the ongoing importance not simply of sex/gender difference but of sex/gender inequality, and the sometimes violent forms that this inequality takes. But they also underscore that these issues can no longer be simply taken for granted, for they have been politicized. As a result, they are recognized by citizens, activists, NGOs, and governments as problems of public importance requiring public solutions. The research and writing contained in this issue of Perspectives demonstrates that political scientists have much to say about these public problems, their public solutions, and the limits of these solutions.

Our lead article, Tali Mendelberg, Christopher F. Karpowitz, and J. Baxter Oliphant's "Gender Inequality in Deliberation: Unpacking the Black Box of Interaction," centers on the role of widespread and general communicative norms in limiting women's political voices and thus their political representation. As the authors summarize their argument: "When and why do women gain from increased descriptive representation in deliberating bodies? Using a large randomized experiment, and linking individual-level speech with assessments of speaker authority, we find that decision rules interact with the number of women in the group to shape the conversation dynamics and deliberative authority, an important form of influence. With majority rule and few women, women experience a negative balance of interruptions when speaking, and these women then lose influence in their own eyes and in others'. But when the group is assigned to unanimous rule, or when women are many, women experience a positive balance of interruptions, mitigating the deleterious effect of small numbers. Men do not experience this pattern." Mendelberg, Karpowitz, and Oliphant link their experimental results to a broader consideration of the political importance of governmental and non-governmental deliberative forums in a range of settings throughout the world, and "the conditioning effect of institutions" in limiting the effective participation of women, and thus limiting both the symbolic and the substantive representation of women's political interests.

There are some important complementarities between this analysis and Jane Mansbridge's 2013 APSA Presidential Address, "What Is Political Science For?" Mansbridge delivers a strong message that is relevant to but also exceeds questions of gender. "The fundamental job of political science," she writes, "is to help us create and properly use legitimate coercion." Mansbridge catalogues the domains in which present day politics comes up short, and insists that political science can play an important role in helping us to generate better and more legitimate collective decisions by promoting "negotiation to agreement" (Mansbridge's text here is usefully read alongside one of this issue's "Undisciplined" features, Sanford 
Levinson's "Compromise, Contestation, and the U.S. Constitution"). As Mansbridge writes: "Because negotiation is such a large part of politics, we need to identify institutions that help negotiators bring in new issues and make good trades. And because one function of institutions is to help correct individual mistakes, we need to figure out what institutions help participants combat the cognitive and emotional barriers to successful negotiation."

Mansbridge's primary purpose here is to promote more inclusive practices of public discourse. She notes that there is some tension between this concern and a good deal of her own work on the contestation of gender inequality: "Viscerally and experientially I identify with resistance. Women, for example, have won most of our gains in the last two centuries by resisting the domination of men. My generation grew up with resistance and our political theory was largely about resistance. Nevertheless, I think the western democratic tradition, anchored in resistance to kings, has focused too much on the possibilities and actualities of tyranny and domination and not enough on the equally important problem of how to create legitimate coercion for collective action." In one sense, her observation here can be linked to her earliest work on Beyond Adversary Democracy. But even if her Address focuses on constructing commonalities rather than on contesting inequalities, both concerns are linked by the theme of inclusion. For it is only by being maximally inclusive that collective decisions can be either effective or legitimate. And a political science that seeks to "help participants combat the cognitive and emotional barriers to successful negotiation" is a political science that necessarily engages precisely the kinds of discursive barriers, distortions, and obstacles to equal participation addressed by Mendelberg, Karpowitz, and Oliphant (who indeed cite Mansbridge's published work on this topic).

At the same time, gender inequality is a complex phenomenon hardly reducible to the discursive realm. Elizabeth Markovits and Susan Bickford's "Constructing Freedom: Institutional Pathways to Changing the Gender Division of Labor" addresses a broader theme-the gendered social division labor. As they write: "individuals make decisions about work and family in an environment marked by a limited set of gendered social scripts, which are then reinforced by particular institutional structures, all of which work to sustain desires and actions in accord with the gender division of labor." Markovits and Bickford thus link the kinds of communicative practices analyzed by Mendelberg, Karpowitz, and Oliphant to the more "material" practices of labor, work, child-rearing and family care that fundamentally structure gender inequality (for a complementary discussion of these connections, see Celeste Montoya's review of Jacqui True's award-winning The Political Economy of Violence Against Women in this issue). Their piece blends normative and empirical concerns, and in arguing for "participatory parity," they gesture toward conceptions of "policy feedback" that have been featured often in our journal, from Suzanne Mettler and Joe Soss's "The Consequences of Public Policy for Democratic Citizenship: Bridging Policy Studies and Mass Politics" (March 2004) to Eileen McDonagh's "It Takes a State: A Policy Feedback Model of Women's Political Representation" (March 2010) to Eric Patashnik and Julian Zelizer's "When Policy Does Not Remake Politics: The Limits of Policy Feedback" (December 2013). As they write: "In addition to fostering 'counterpublic' spaces and cross-public conversations, feminists have long been engaged in struggle over public policy. Public policies that structure women's options affect what women are able to choose, regardless of what they desire; but they also affect what women desire because they work to ideologically support certain options. Public policies thus play a role in conditioning women's desires, as the options they support 'feel' right and are easier or at least imaginable. When these policies sustain unequal divisions of household labor and women's underrepresentation in the public sphere, they also affect women's power and participation in the terms and processes of social construction." Markovits and Bickford thus conclude that public policy is both a key determinant of gender inequality and a potential source of greater equality.

Heath Fogg Davis's "Sex-Classification Policies as Transgender Discrimination: An Intersectional Critique” analyzes a more fundamental dimension of gender inequality - the very determination of the categories of "man" and "woman," and the ways that these very binary categories marginalize and exclude transgendered individuals. Fogg Davis proceeds from a very specific episode: the Philadelphia Bus Authority's treatment of Charlene Arcila, an African-American transgender woman who was denied bus access because her monthly public transit pass was considered invalid both when marked with an $\mathrm{F}$ to signify female gender and when marked with an $\mathrm{M}$ to signify male gender. Fogg Davis uses this episode of an individual who did not "fit" and who was thus denied access to public transportation, to tell a rich political story of Arcila's civil rights litigation with the city; the activism of R.A.G.E. (Riders Against Gender Exclusion), a local grassroots organization which sprouted in 2009 to bring public attention to the invidious impact of the gender sticker policy; and the legal and political argumentation surrounding the case.

In telling this story, he underscores a dimension of gender inequality that is often ignored: "Personal identification documents such as driver's licenses, passports, and birth certificates bear mandatory binary sex markers. We are asked to tick binary sex boxes on many bureaucratic forms ranging from school, job, mortgage and apartment rental applications, to government census forms, and dental and medical in-take questionnaires. And we live in a society in which most public restrooms, change room 
facilities, and all prisons, are designed, constructed and designated as sex-segregated. The invidious nature of these sex-classificatory schemes may be hard for many people to fathom because they are so customary, and because most people experience them as mere moments of cursory verification of who they are and where they ought to be. Moreover, these policies do not fit the model of traditional sex discrimination, which has focused on policies that disadvantage women in relationship to men, and vice versa. However, for those of us who appear to some to be stretching conventional binary sex categories 'too far,' sexclassification policies cause significant vulnerability to invasive questioning, verbal ridicule, exclusion, and even physical violence by administrative agents, and the public at large." Like Markovits and Bickford, Fogg Davis blends normative, empirical, and jurisprudential analysis, highlighting the importance of gender classificatory schemes that are often taken for granted, and calling for the consistent deployment of antidiscrimination law to eliminate the vast majority of these schemes in the name of civic equality.

If our first three research articles center on the sources of sex/gender inequality, each also indicates ways that such inequality can be politicized and challenged. Such politicization is the focus of Kimberly B. Cowell-Meyers's "The Social Movement as Political Party: The Northern Ireland Women's Coalition and the Campaign for Inclusion." As Cowell-Meyers writes, "This article considers one particular device for enhancing the inclusiveness and responsiveness of the representative system that has largely been overlooked by scholars to date. The subject is a movement-party, an unusual but not entirely rare institution. In particular, it considers the Northern Ireland Women's Coalition, which, despite being small, marginal and short-lived, left its mark on the political system in Northern Ireland, by promoting women's descriptive and substantive representation in nearly all the other political parties in the system." Cowell-Meyers argues that the Coalition's organizers "formed a political party to blackmail the other parties into granting their own women access as candidates, representatives, and leaders," and that through this effort "women managed to break through the cultural prejudices against women in politics, and change popular and elite attitudes. . altering the terms of representation and enhancing the inclusiveness of the political process." (The themes of gender mobilization and representation are also explored in this issue's Critical Dialogue between Kristin A. Goss, author of The Paradox of Gender Equality: How American Women's Groups Gained and Lost Their Public Voice and Holly J. McCammon, author of The U.S. Women's Jury Movements and Strategic Adaptation: A More Just Verdict.)

This issue's final two research articles also center on broad questions of inclusion and representation, though without a focus on gender. Zoltan L. Hajnal and Jeremy D. Horowitz's "Racial Winners and Losers in American
Party Politics" offers a careful empirical analysis of the relative well being of African-Americans, Latinos, and Asian-Americans under Democratic and Republican administrations in the United States. As they write: "We trace the well-being of racial and ethnic minorities over time using objective, empirical measures, and then compare the relative progress of these demographic groups under different partisan regimes. Specifically, we test to see whether blacks and other racial and ethnic minorities fare better on basic indicators of well being like income, poverty, and unemployment when Democrats control the presidency or whether they do better under Republican administrations." And they conclude that "When the nation is governed by Democrats, racial and ethnic minority well-being improves dramatically. By contrast, under Republican administrations, blacks, Latinos, and Asian Americans generally suffer losses." As Hajnal and Horowitz make clear, these contemporary disparities relate to long-standing racial inequalities in the United States. Their piece can thus be read alongside our issue's second "Undisciplined" feature, Rick Valelly's review essay, "Slavery, Emancipation, and the Civil War Transformation of the U.S. State" Valelly's piece is a tour de force. Reviewing a group of recent books on the history of the U.S. Civil War (most of them written by professional historians, though one is written by a political science scholar of "APD"), Valelly analyzes the ideological and political struggles and dynamics leading to the Civil War; the role of arguments about slavery and its abolition in these struggles; the sometimes intended and sometimes unintended consequences of the actions of politicians like Stephen Douglas and Abraham Lincoln; and the ways in which the politics of War and Reconstruction both dramatically and haltingly contributed to the growth of the power of the American central state. Indeed, both of our "Undisciplined" review essays, by Vallely and Sanford Levinson, underscore the complexity and contingency through which the American state and its Constitution have developed over time.

Paul Frymer's "A Rush and a Push and the Land is Ours': Territorial Expansion, Land Policy, and U.S. State Formation" is a rich descriptive account, based on extensive archival research, of $19^{\text {th }}$ century land policy in the United States. Frymer details the territorial expansion of the United States, treating it as a form of state-building and a means of dispersal and control of immigrant, settler, and native populations. As Frymer writes: "Land policies offered government officials an institutional mechanism for taking territory that manufactured racially-specific outcomes with less public visibility, enabling the government to maintain at least the appearance of fidelity to national ideals. Indian removal and the violence it entailed cannot be minimized - the actions of the United States during this period would constitute genocide under current-day international law. But the Indian Removal Act was only one piece of a far broader, systematic, 
efficacious, and yet 'unexceptional' taking of land. Legislators clearly intended that these land policies could change the racial demographics of a specific geographical terrain; they designed statutes such as the Armed Occupation Act, the Land Donation Act, the Preemption Act, and the Homestead Act to move as many settlers as possible on to contested lands to overwhelm and numerically dominate the pre-existing populations. Only after this successful rush and push created a majority of whites residing in the territory would Congress vote to formally incorporate the land as a state." As Frymer's article makes clear, the "extended republic" envisioned by James Madison and other framers of the Constitution was accomplished through state policies of infrastructural expansion, population removal, resettlement and settlement, and extensive violence against native populations that were heavily inflected by class and race.

Frymer's account of the territorial expansion that accompanied the growth of the U.S. state is broadly consistent with a wide range of theories in comparative politics and international relations theory that focus on what might be called "the logic of state power" in the world of power politics. Frymer does not discuss gender in this connection, though works such as Amy S. Greenberg's Manifest Manhood and the Antebellum American Empire (Cambridge University Press, 2005) make clear that conceptions of masculinity and femininity played an important role in justifying American westward expansion. One of the reasons why Laura Sjoberg's Gendering Global Conflict: Toward a Feminist Theory of War is so important is that it makes clear that every aspect of modern power politics, and especially those dimensions of power politics that relate to war and peace, are heavily inflected by gender (see also Jessica Peet's review of Valerie M. Hudson's Sex and World Peace). Sjoberg argues that the fields of international relations and security studies are impoverished by an insufficient attention to the gendering of conflict, and that a "feminist theory of war" is therefore indispensable to an adequate understanding of the politics of war. We are thus especially pleased to feature a symposium on her book that features commentaries by Cynthia Enloe, Sara Meger, Elisabeth P. Prügl, Matthew Hoddie, and Dustin Howes.

We are also pleased to include a special discussion of Celeste Montoya's Global to Grassroots: The European Union, Transnational Advocacy, and Combating Violence Against Women, which features perspectives on the book from an Eastern European feminist scholar (Oana Baluta) and a U.S. scholar (Mary Hawkesworth).

Our special review section on Gender and Politics contains reviews of a wide range of political science books. These reviews make clear that gender is a central theme of political science that crosses all conventional subfield and methodological divides in our discipline. At the same time, this issue also contains a great number of reviews that fall more or less neatly under the conventional subfield rubrics. The range of articles, essays, reviews, review essays, and dialogues that appear here demonstrates the synergies between genres and perspectives that make political science an intellectually rich and productive discipline.

With this issue, Perspectives begins its twelfth year. Over those twelve years a great many people have contributed to the journal as editors, associate editors, and editorial assistants. I am very pleased that during my tenure our entire editorial board has continued to serve, with enthusiasm. I am also pleased to note that we recently have added a number of terrific colleagues to our board, and I would like to welcome them here: Michael Bernhard, Charli Carpenter, Ange-Marie Hancock, Marc Lynch, Samantha Majic, Andrew Sabl, Joe Soss, and Paul Staniland. A complete list of our board appears on our masthead. We all owe these colleagues a debt of gratitude for the work they do for our journal.

I would also like to thank Michael Brintnall, who recently retired as APSA's long-standing Executive Director, for his extraordinary service to our discipline and for his support of our journal. Michael was a terrific colleague, and we look forward to working with his successor, Steven R. Smith, who is off to a great start.

My editorial team has experienced its share of turnover over the years. This year one of our longest-serving and most invaluable editorial assistants, Emily Hilty, earned her Ph.D. and left our staff for a position as Visiting Assistant Professor of Political Science at University of Cincinnati. Emily was replaced by Rachel Gears, who joins our current team of crackerjack editorial assistants: Laura Bucci, Peter Giordano, Rafael Khachaturian, Brendon Westler, and Adrian Florea (Adrian, a brilliant young scholar of comparative politics and international relations, recently returned to our staff after holding a competitive dissertation writing fellowship, and he plays an indispensible role in bridging the front and back ends of the journal).

Ever since I first became Book Review Editor in 2005, I have been graced with the dedicated and indefatigable support of two people who I've mentioned frequently: James Moskowitz and Margot Morgan. When I became Editor in Chief, James became our journal's full-time Managing Editor. Shortly thereafter, Margot earned her $\mathrm{Ph} . \mathrm{D}$. from Rutgers and became our full-time Book Review Managing Editor. James and Margot have been my indispensible partners, and what our journal has accomplished under my editorial tenure has only been possible because of their extraordinary collaboration. In August of 2013 Margot left our staff for a position as Visiting Assistant Professor of Political Science at Indiana University Southeast in New Albany, Indiana. She is greatly missed. At the same time, I am pleased to note that her book, Politics and Theatre in Twentieth-Century Europe: Imagination and Resistance, was published by 
Palgrave Macmillan in December 2013. I am also pleased to note that James Moskowitz, Perspectives on Politics's own version of NBA great Allen Iverson—nicknamed "The
Answer"- has incorporated the Book Review into his already extensive responsibilities, and remains with us for the duration. I could not do this without him. 